\title{
SUPPLIER-CUSTOMER RELATIONSHIPS: WEAKNESSES IN SOUTH AFRICAN AUTOMOTIVE SUPPLY CHAINS
}

\author{
MJ NAUDE* \\ PROF JA BADENHORST-WEISS** \\ *NaudeM@ukzn.ac.za \\ School of Management, Information Technology and Governance \\ University of KwaZulu-Natal \\ **Department of Business Management \\ University of South Africa (Unisa)
}

\begin{abstract}
The South African automotive industry, which is an important sector in the South African economy, needs to function efficiently if it is to compete internationally. However, South African automotive components manufacturers (ACMs) are not internationally competitive and automotive assemblers, also known as original equipment manufacturers (OEMs), often import cheaper components from abroad. All parties in the South African automotive supply chains need each other to ensure optimal efficiency and competitiveness. Furthermore, it is vital that good relationships exist between customers and suppliers in the automotive supply chains in South Africa. ACMs are central to automotive supply chains. A survey was conducted among $\mathrm{ACM}$ s to determine the nature of relationships that exist between buyers and suppliers in South Africa's automotive supply chains. The results showed that collaborative relationships do indeed exist between members of the supply chain but that communication, understanding of the parties' situations and cooperation can improve this relationship and so create total alliance between OEMs and ACMs.
\end{abstract}

\section{INTRODUCTION}

The automotive industry makes a significant contribution to the South African economy (Automotive Industry Export Council [AIEC], 2011: 13). Original equipment manufacturers (OEMs), such as Toyota, and their suppliers - automotive component manufacturers (ACMs) - are important role-players in the South African automotive industry. The survival and growth of these businesses in an ever-increasing competitive global market are of the utmost importance for the South African economy. However, these businesses will only survive and grow if they are able to compete internationally. The problem is that some South African ACMs, from a financial perspective, are simply not competitive. As indicated by Venter (2009a \& 2009b), on average, South African-made components are $20 \%$ more expensive than those from Western Europe and 30 to $40 \%$ more expensive than those from 
China and India. Consequently, local OEMs purchase many components from low-cost part suppliers abroad. South African ACMs therefore have to compete against cheap imported components. This is clearly reflected by the low percentage of local content (an average of $35 \%$ ) in finished motor cars (Pitot, 2007). If South African ACMs can succeed in becoming more efficient and competitive, an increasing number of local and even some international OEMs will be inclined to purchase components from them which, in turn, will lead to further economies of scale.

To compete internationally, the focus is no longer on the management, survival, growth and competitiveness of individual organisations but on supply chains (Chan \& Qi, 2003 : 209; Christopher, 2005: 202). Companies no longer compete against companies. Instead, supply chains compete against other supply chains for supremacy: '... Toyota and its suppliers will clash with Ford and its suppliers' for global competitive advantage (Fawcett, Ellram \& Ogden, 2007: xvii). The South African automotive industry, as part of the most global of industries, also follows the international trend of implementing lean production, modularisation, outsourcing and the organisation of the different role-players in supply chains, with a management focus on the operations of the supply chain as a whole. These trends have an enormous impact on the relationships between OEMs and their suppliers, particularly those in the first tier, known as ACMs (Morris, Donnelly \& Donnelly, 2004: 129).

Supply chain management (SCM) developed as a management philosophy or practice when businesses realised that both customers and suppliers can exert considerable influence on supply processes. Organisations need their suppliers to assist in decreasing costs, improving customer service and efficiency. Also, their customers need their cooperation to further decrease costs, improve customer service and efficiency (Van Weele, 2010: 254-55): '[T]he relationship between the company and its suppliers as well as its customers is included in the concept [of SCM].'

Against this background, an exploratory study in the form of a survey was conducted among ACMs to determine relationship weaknesses that might lead to a lack of competitiveness in some components of automotive supply chains. ACMs are at the centre of automotive supply chains and are thus in a good position to identify customer and supplier relationship weaknesses. This article focuses on supply chain relationships and reports on the findings of a previous study by Naude and Badenhorst-Weiss (2011a) that identified certain weaknesses in South African automotive industry's supply chains.

\section{RESEARCH STRATEGY}

The study that informed this article was descriptive and exploratory and contained both quantitative and qualitative elements. The literature study focused on the supply chain management approach and the relationships in supply chains. 
The research problem of the study was to determine whether weaknesses (identified in a previous study by Naude and Badenhorst [2011a]) in the supplier-customer relationships that exist between ACMs, their suppliers and customers were statistically significant. In line with the research problem, the objectives of this research were to:

- determine whether relationship weaknesses that exist on the supplier side and customer side were statistically significant

- provide insight into relationships that exist between ACMs, their suppliers and customers.

The empirical research involved two phases. The first phase consisted of semi-structured interviews with management personnel at executive and senior level, at two leading OEMs in South Africa. The purpose of these interviews was to obtain insight into possible weaknesses or shortcomings in automotive supply chains in order to compile a questionnaire that could be used in the second part of the empirical study. A questionnaire was designed to test identified weaknesses or shortcomings facing automotive supply chains, with a specific focus on existing weaknesses in supplier and customer relationships.

The second phase of the study consisted of e-mailing the questionnaire to all ACMs belonging to the National Association of Automotive Component and Allied Manufacturers (NAACAM). It is estimated that $60 \%$ of the largest and most important ACMs are members of NAACAM (Barnes, 2002: 56). A membership list was obtained from the association. Completed questionnaires were returned to the researcher via e-mail. A total of 173 questionnaires was sent out and a response rate of $30.6 \%$ was achieved. The profile of the respondents is provided in Annexure A. ACMs are at the centre of automotive supply chains and are thus in a good position to identify customer and supplier relationship weaknesses.

The questionnaire consisted of two sections: A and B. Section A dealt with respondents' profiles. Section B of the questionnaire was compiled to measure the extent to which the responding ACMs experience various supply chain weaknesses outlined in the questionnaire. This section of the questionnaire used a seven-point Likert scale (ordinal scale) varying from 1 (to a lesser extent) to 7 (to a greater extent). The questionnaire also included a qualitative section to determine why companies are experiencing weaknesses. It also allowed respondents, if they wished to do so, to clarify an issue or to express their opinions if they felt very strongly about one of the issues mentioned.

Descriptive statistics were used to explore the data collected and to summarise and describe the data. Mean and median analysis gave an adequate perspective of and insight into the results. Weaknesses with a mean rating of $>3.7$ on the supplier and customer sides are included in this study and are indicated in Tables 1 and 2. A binomial test was used to test whether the weaknesses in the relationships that exist between ACMs, their suppliers and 
customers (OEMs) - as illustrated in Figure 1 - are statistically significant. The results of this study are dealt with in the section that analyses the findings.

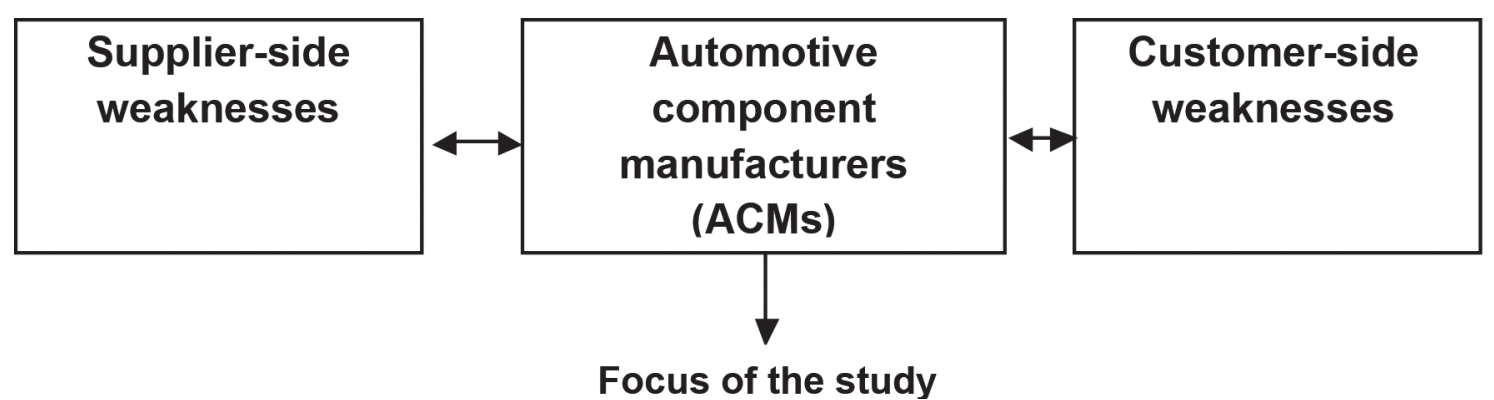

Figure 1: Relationships between ACMs, their suppliers and customers Source: Adapted from Naude \& Badenhorst-Weiss (2011b)

\section{LITERATURE REVIEW}

\section{The automotive industry}

The global automotive industry is a key sector of the economy of every major country in the world (TISA, 2003: 6). As indicated in AIEC (2011: 12), vehicle manufacturing requires the employment of about 9 million people who actually manufacture the vehicles and automotive components. This comprises over $5 \%$ of the world's total manufacturing employees. Many people are also employed in automotive-related manufacturing and services because the sector relies on the goods produced by many industries (including, among others, steel, iron, aluminium, glass, plastics, carpeting, textiles, computer chips and rubber). It is estimated that each direct automotive job supports at least another five indirect jobs, resulting in more than 50 million jobs globally being created by the automotive industry (AIEC, 2011: 12).

The automotive industry in South Africa is a major contributor to the Gross Domestic Product (GDP), and to export and employment opportunities. In 2010 the automotive industry contributed $6.17 \%$ of the GDP. Despite the fact that certain components suppliers (ACMs) are not internationally competitive, the automotive industry contributed $11.9 \%$ of total exports, to the value of R584 billion, in finished cars and components - mainly to China, the USA, Japan, Germany and the UK (AIEC, 2011: 7). OEMs in South Africa employ more than 32000 people (NAAMSA, 2010) and ACMs more than 65000 people (NAACAM, 2009: 1); ACMs, therefore, are the main contributors of employment opportunities. However, as indicated previously, many ACMs are not internationally competitive. It was therefore deemed necessary to conduct a study of existing supply chain weaknesses and to identify any problems experienced in the relationships between ACMs, their suppliers and their customers. 


\section{Development and management of supply chain relationships}

Resource dependence theory (RDT) confirms the fact that since businesses operate within a network of exchange relationships they are dependent on other businesses for survival. The main focus of RDT is on how some businesses become dependent on other businesses for survival (Pfeffer \& Salancik, 1978: 3; Tiziana \& Mikolaj, 2005: 167). Every business - whether in the public or private sector - is dependent on materials and services supplied by other businesses. Since no business is self-sufficient, it can be concluded that sound relationships within the supply chain are vital to businesses.

Traditionally, businesses focused on their customers - hence, the slogan 'The customer is king' and the development, some decades ago, of the concept of customer relationship management (Burt, Petcavage \& Pinkerton, 2010: 66). However, this has changed. Liker and Choi (2006: 23) contend that businesses largely rely on their suppliers to reduce costs, enhance quality and develop innovations faster than their competitors' suppliers. One way of achieving this is to build relationships with suppliers who are able to learn, improve and grow. It is crucial that supplier relationships between parties be based on trust.

This became clear when the Harvard Business Review organised a team of leading academics in the discipline of supply chain management. People and relationships were identified as the major themes for discussion. For example, it was established that the opportunities and challenges of globalisation and the continual demand for speed and cost containment were compelling businesses to establish relationships with their suppliers (Beth, Burt, Copacino, Gopal, Lee, Lynch \& Morris, 2006: 65). A relationship and collaboration with suppliers gave rise to the concept of supplier relationship management.

According to Monczka, Handfield, Giunipero, Patterson and Waters (2010: 109), most suppliers and customers recognise the need for collaboration as the best way of improving costs, quality, delivery, time schedules and other measures of performance. The relationship is bilateral, which means that both parties have the power to shape its nature and future direction. Mutual commitment and balanced power are key features - commitment to enable both parties to keep the relationship working over a time period, and balance to ensure mutual benefits.

Burt et al. (2010: 65) acknowledge that buyer-supplier (or supplier-customer) relationships have evolved from being transactional to collaborative to alliance-based. For example, OEMs in South Africa hold a strong position in the automotive industry and because of this strength adversarial relationships have developed with component suppliers. However, as a result of the lifting of the protection of local industries, relationships both up and down the supply chain have had to change, and partnerships are now being created (Williams, 2004: 1). Traditionally, the belief was that the outcome of an adversarial relationship is 
perceived in terms of 'win-lose' results, whereas the outcome of a partnership relationship is perceived to result in a 'win-win' situation - both sides winning at the same time by adopting a problem-solving approach (Saunders, 1996: 255). However, according to Fawcett et al. (2007: 347) and Swink, Melnyk, Cooper and Hartley (2011: 294-95) the key is not 'win-win' or 'win-lose' but an appropriate relationship. This is in accordance with strategic sourcing principles. Some suppliers of less significant, standard materials and services receive only limited attention in what can only be described as an 'arm's-length relationship'. However, since the emergence of the supply chain management concept two decades ago, the focus has shifted to longer-term engagement and relationships with suppliers of critical and bottleneck materials or services (Ganesan, Brown, Mariadoss \& Ho, 2010: 361; Gullett, Do, Canuto-Carranco, Brister, Turner \& Caldwell, 2010: 330; Wu \& Weng, 2010: 392).

Instead of adhering to the notion of the 'win-lose' and 'win-win' relationship, Burt et al. (2010: 66) distinguish between transactional, collaborative and alliance-type relationships. In the transactional category, Swink et al. (2011: 294-95) distinguish between an adversarial relationship and an arm's-length relationship. Adversarial relationships are characterised by distrust and limited communication (a typical win-lose relationship) and have no place in supply chain management. An arm's-length relationship tends to be limited to simple purchasing transactions, but at the same time lacks distrust and antagonism. Lysons and Gillingham (2003: 378) define a transactional relationship as '[a] straightforward relationship between buyer and seller whereby the two parties do not get closely involved with each other, but simply exchange goods or services for payment'. Burt et al. (2010: 66) support this definition by describing this kind of relationship as neither good nor bad - it is merely an arm's-length relationship in which neither party is particularly concerned with the other's interests. In a collaborative relationship, the buyers and suppliers accept mutual goals but lack the resources associated with a full partnership. In a full partnership (also known as a strategic alliance), buyers and suppliers have a close working relationship, in which there is trust and mutual respect, with highly semi-structured integrated operations, access to each other's strategic plans in the area of interface (e.g. cost information and forecasting), and openness in dealing with risks and incentives (Webster, 2008: 94; Burt et al., 2010: 68-72). Business owners and executives are beginning to realise that strategic supplier alliances, if successful, can result in better market penetration, access to new technology and knowledge and higher returns on investment than competitors that do not have such alliances (Wisner, Tan \& Leong, 2008: 120). Swink et al. (2011: 295) cite the example of the Ford Motor Company in Brazil, where suppliers of wiring dashboards and seats work side-by-side with Ford employees, in a trusting partnership relationship, to create better solutions than they can create alone.

There is an imbalance of power in the automotive industry. OEMs enjoy a high level of dominance (power) which may tilt the scale in their favour in the relationship and negotiations 
with ACMs (Wisner et al., 2008: 122). Lysons and Gillingham (2003: 378) recognise 'power relationships' that afford one company a negotiation advantage over another. These power relationships can develop from factors such as size, volume of business, environmental conditions and ownership by one party of some asset that the other party simply does not have. Gullett et al. (2010: 331) contend that trust (among buyers and sellers in an alliance) must rise to the level of a behaviour that demonstrates the degree to which an individual is personally willing to surrender control to the party being trusted. As a result of the rejection of using the position of power in buyer-supplier relationships, some people are critical of the concepts of 'customer relationship management' and 'supplier relationship management'. The concept 'relationship management' implies that one party in the supply chain has the power to manage the other party.

Compared with transactional relationships, collaborative and alliance relationships are inclined to result in lower total costs.

ACMs provide important components, modules and services to the OEMs' production and assembly process. Alliances between ACMs and OEMs are therefore the most appropriate relationship in automotive supply chains. Quesada, Syamil and Doll (2006: 30) acknowledge that in industries such as the automotive industry, where value added by suppliers contributes significantly to the final product, the competitiveness of OEMs depends on supplier performance in terms of cost, quality and on-time delivery. Consequently, supply, sourcing and purchasing professionals believe strongly that more and stronger supplier partnerships are critical to achieving competitive corporate performance (Morgan, 2001).

The question is whether the appropriate relationships exist in automotive supply chains in South Africa. In the empirical study described below an effort is made to provide insight into the supply chain weaknesses in the relationships that exist between suppliers and buyers. Many commodities, important raw materials, components and modules to be assembled in finished cars are supplied throughout the automotive supply chain. A partnership relationship seems to be the most appropriate relationship in automotive supply chains.

\section{FINDINGS OF THE EMPIRICAL STUDY}

The aim of the study was to identify possible supply chain weaknesses and aspects that may have had an impact on supplier and customer relationships, from the ACMs' perspective, and to determine the extent of the weaknesses. If the relationship weaknesses were found to be insignificant then the relationships were sound. Only the factors that may have contributed to supplier-relationship and customer-relationship weaknesses that tested significant are included in this article. These are listed in Tables 1 and 2 below. 
In order to achieve the objectives, the following hypotheses were formulated to guide the research.

\section{Hypothesis 1}

H01: Supply chain relationship weaknesses that exist between ACMs and their suppliers are not significant.

Ha1: Supply chain relationship weaknesses that exist between ACMs and their suppliers are significant.

A binomial test was used to test whether existing weaknesses in relationships between ACMs and their suppliers were significant. The test determined whether the proportion of respondents in Group 2 (defined below) is different from what is expected for a population where there is neutrality $(p=0.05)$ regarding the extent of supply chain weaknesses. The identified weaknesses were ranked from a greater to a lesser extent. The two groups were formed by grouping the responses 'to a lesser extent' together, coded as a 1 (category 1), and responses 'to a greater extent' together, coded as a 2 (category 2). It was thus possible to determine whether a weakness was perceived as being significant (the proportion of 'greater extent' responses) or not, as indicated in Table 1.

Table 1: Hypothesis 1: Significant supplier-side weaknesses ( $N=53)$

\begin{tabular}{|c|c|c|c|c|c|c|}
\hline & \multicolumn{5}{|c|}{ Frequency testing } & Mean rating \\
\hline & \multicolumn{5}{|c|}{ Supplier-side weaknesses } & \\
\hline 1. & \multicolumn{5}{|c|}{ Trust between you and your 'worst $10 \%$ ' of suppliers } & 3.73 \\
\hline 2. & \multicolumn{5}{|c|}{ Material lead times (too long) from suppliers } & 4.02 \\
\hline 3. & \multicolumn{5}{|c|}{ Price of materials from suppliers } & 4.38 \\
\hline 4. & \multicolumn{5}{|c|}{ Financial stability of suppliers (after the recent economic crisis) } & 4.09 \\
\hline \multicolumn{7}{|c|}{ Binomial tests } \\
\hline & Category & $\mathbf{N}$ & $\begin{array}{l}\text { Observed } \\
\text { prop }\end{array}$ & Test prop & $\begin{array}{l}\text { Asymp sig } \\
\text { (2-tailed) }\end{array}$ & $\begin{array}{c}\text { Statistical } \\
\text { significance } \\
(p<0.05)\end{array}$ \\
\hline $\begin{array}{l}1 . \\
\text { Total }\end{array}$ & $\begin{array}{l}2 \\
1\end{array}$ & $\begin{array}{l}34 \\
10 \\
44 \\
\end{array}$ & $\begin{array}{r}.77 \\
.23 \\
1.00 \\
\end{array}$ & .50 & $.000^{\mathrm{a}}$ & Significant \\
\hline $\begin{array}{l}2 . \\
\text { Total }\end{array}$ & $\begin{array}{l}1 \\
2\end{array}$ & $\begin{array}{l}14 \\
32 \\
46 \\
\end{array}$ & $\begin{array}{r}.30 \\
.70 \\
1.00 \\
\end{array}$ & .50 & $.011^{\mathrm{a}}$ & Significant \\
\hline $\begin{array}{l}3 . \\
\text { Total }\end{array}$ & $\begin{array}{l}2 \\
1\end{array}$ & $\begin{array}{l}39 \\
11 \\
50 \\
\end{array}$ & $\begin{array}{r}.78 \\
.22 \\
1.00 \\
\end{array}$ & .50 & $.000^{\mathrm{a}}$ & Significant \\
\hline $\begin{array}{l}\text { 4. } \\
\text { Total }\end{array}$ & $\begin{array}{l}2 \\
1\end{array}$ & $\begin{array}{r}36 \\
7 \\
43\end{array}$ & \begin{tabular}{r|}
.84 \\
.16 \\
1.00
\end{tabular} & .50 & $.000^{a}$ & Significant \\
\hline
\end{tabular}

a Based on $\mathrm{Z}$ approximation 
Only weaknesses that were statistically significant (a mean <3.7) are included in Table 1. Only four of possible 14 weaknesses to the supplier side were tested as significant: trust between ACMs and their 10\% worst suppliers (mean 3.73); material lead times of incoming materials too long (mean 4.02); price of purchased materials (mean 4.38); and financial stability of suppliers (mean 4.09).

From the findings it seems that, in general, a good relationship exists between ACMs and their suppliers. The weaknesses they experienced were related to trusting $10 \%$ of their worst customers. On the positive side, the respondents indicated that trust between them and their best customers was not a problem. The problem of financial instability brings a feeling of uneasiness into the relationship. The other significant weaknesses cannot be linked to relationships between suppliers and ACMs.

It can be concluded that relationships with suppliers in general do not constitute a significant problem for ACMs. In cooperation with suppliers, they can try to find solutions for the long lead times; this in turn, will improve the inventory situation and cost efficiencies. In the same way they should try to find innovative solutions for the high material prices. Innovative solutions may include ways to reduce costs or to improve work performance. ACMs and their suppliers do not have control over economic conditions. They have to apply the survival strategies which most businesses have recourse to in weak economic conditions.

\section{Hypothesis 2}

H02: Supply chain relationship weaknesses that exist between ACMs and their customers (OEMs) are not significant.

$\mathrm{Ha}$ 2: Supply chain relationship weaknesses that exist between ACMs and their customers (OEMs) are significant.

In the same way as explained above, a binomial test was used to test whether weaknesses in the relationships between ACMs and their customers (OEMs) were statistically significant. The findings are indicated in Table 2. 
Table 2: Hypothesis 2: Significant customer-side weaknesses $(N=53)$

\begin{tabular}{|c|c|c|c|c|c|c|}
\hline & \multicolumn{5}{|c|}{ Frequency testing } & Mean \\
\hline & \multicolumn{5}{|c|}{ Customer-side weaknesses } & \\
\hline 1. & \multicolumn{5}{|c|}{ Relationship with 'worst $10 \%$ ' of customers } & 4.12 \\
\hline 2. & \multicolumn{5}{|c|}{ Trust between you and your 'worst' customers } & 4.13 \\
\hline 3. & \multicolumn{5}{|c|}{ Advance communication about market demand } & 4.15 \\
\hline 4. & \multicolumn{5}{|c|}{ Cancellation of orders (after the recent economic crisis) } & 5.02 \\
\hline 5. & \multicolumn{5}{|c|}{ Excessive slow-moving inventory owing to order cancellations } & 4.83 \\
\hline 6. & \multicolumn{5}{|c|}{ Pressure by OEMs to reduce prices } & 5.51 \\
\hline 7. & \multicolumn{5}{|c|}{ Little/no assistance from customers in complying with their requirements } & 3.79 \\
\hline 8. & \multicolumn{5}{|c|}{ Rapid changes in demand (in terms of quantity) patterns } & 4.18 \\
\hline 9. & \multicolumn{5}{|c|}{ Too dependent on the business of one specific customer } & 4.15 \\
\hline \multicolumn{7}{|c|}{ Binomial tests } \\
\hline & Category & $\mathbf{N}$ & $\begin{array}{l}\text { Observed } \\
\text { prop }\end{array}$ & Test prop & $\begin{array}{l}\text { Asymp sig } \\
\text { (2-tailed) }\end{array}$ & $\begin{array}{c}\text { Statistical } \\
\text { significance } \\
(p<0.05)\end{array}$ \\
\hline $\begin{array}{l}1 . \\
\text { Total }\end{array}$ & $\begin{array}{l}1 \\
2\end{array}$ & $\begin{array}{r}6 \\
28 \\
34\end{array}$ & $\begin{array}{r}.18 \\
.82 \\
1.00\end{array}$ & .50 & $.000^{a}$ & Significant \\
\hline $\begin{array}{l}2 . \\
\quad \text { Total }\end{array}$ & $\begin{array}{l}1 \\
2\end{array}$ & $\begin{array}{r}9 \\
30 \\
39 \\
\end{array}$ & $\begin{array}{r}.23 \\
.77 \\
1.00 \\
\end{array}$ & .50 & $.001^{\mathrm{a}}$ & Significant \\
\hline $\begin{array}{l}3 . \\
\text { Total } \\
\end{array}$ & $\begin{array}{l}1 \\
2\end{array}$ & $\begin{array}{r}7 \\
34 \\
41 \\
\end{array}$ & $\begin{array}{r}.17 \\
.83 \\
1.00 \\
\end{array}$ & .50 & $.000^{a}$ & Significant \\
\hline $\begin{array}{l}\text { 4. } \\
\text { Total }\end{array}$ & $\begin{array}{l}2 \\
1\end{array}$ & $\begin{array}{r}44 \\
5 \\
49\end{array}$ & $\begin{array}{r}.90 \\
.10 \\
1.00\end{array}$ & .50 & $.000^{a}$ & Significant \\
\hline $\begin{array}{l}\text { 5. } \\
\text { Total }\end{array}$ & $\begin{array}{l}1 \\
2\end{array}$ & $\begin{array}{r}6 \\
41 \\
47\end{array}$ & $\begin{array}{r}.13 \\
.87 \\
1.00\end{array}$ & .50 & $.000^{a}$ & Significant \\
\hline $\begin{array}{l}\text { 6. } \\
\text { Total }\end{array}$ & $\begin{array}{l}2 \\
1\end{array}$ & $\begin{array}{r}45 \\
4 \\
49\end{array}$ & $\begin{array}{r}.92 \\
.08 \\
1.00\end{array}$ & .50 & $.000^{a}$ & Significant \\
\hline $\begin{array}{l}7 . \quad \\
\text { Total }\end{array}$ & $\begin{array}{l}1 \\
2\end{array}$ & $\begin{array}{l}11 \\
32 \\
43 \\
\end{array}$ & $\begin{array}{r}.26 \\
.74 \\
1.00 \\
\end{array}$ & .50 & $.002^{a}$ & Significant \\
\hline Total & $\begin{array}{l}1 \\
2\end{array}$ & $\begin{array}{r}8 \\
36 \\
44\end{array}$ & $\begin{array}{r}.18 \\
.82 \\
1.00\end{array}$ & .50 & $.000^{a}$ & Significant \\
\hline 9. & $\begin{array}{l}2 \\
1\end{array}$ & $\begin{array}{l}29 \\
12 \\
41\end{array}$ & $\begin{array}{r}.71 \\
.29 \\
1.00\end{array}$ & .50 & $.012^{a}$ & Significant \\
\hline
\end{tabular}

\footnotetext{
a Based on $\mathrm{Z}$ approximation
}

Only the statistically significant weaknesses (a mean $>3.7$ ) are reflected in Table 2. Nine possible weaknesses related to the customer side of ACMs that were tested were significant: the relationship with the worst $10 \%$ customers (on a seven-point scale, mean 4.12 ); trust 
between ACMs and worst $10 \%$ of customers (mean 4.13); advance communication about market demand (mean 4.15); cancellation of orders (after the recent economic crisis) (mean 5.02); excessive slow-moving inventory owing to cancellations of orders (mean 4.83); pressure by OEMs to reduce prices (mean 5.51); little or no assistance from customers to comply with their requirements (mean 3.79); rapid changes in demand (in terms of quantity) patterns (mean 4.18); and being too dependent on the business of a particular customer (4.15).

ACMs indicated the existence of weaknesses with the worst $10 \%$ customers to a significant extent when responding to the questionnaire items on relationship and trust. However, ACMs did not regard relationships and trust as weaknesses with other, good customers (OEMs) as significant weaknesses, although ACMs did feel that OEMs could assist them more in complying with their (OEMs') requirements. ACMs regarded a lack of advanced communication about the required market demand by OEMs as a significant problem. Cooperation and communication between ACMs and OEMs are therefore deemed to be areas that need attention.

It seems that adverse economic conditions caused OEMs to cancel orders at ACMs, and that this was a significant problem for them (5.02). A consequence of the cancellation of orders is reflected in the significant problem of excessive, slow-moving inventory.

ACMs felt to - a significant extent - that the pressure from OEMs to reduce prices (5.51) was a problem for them. OEMs, who are the most powerful parties in automotive supply chains, face stagnant demand, an oversupply of motor vehicles and tough price competition. It is thus imperative for them to keep costs down and, as a direct result, OEMs put pressure on ACMs to reduce the prices of purchased goods.

The problem of rapid changes in demand is also a significant supply chain problem (4.18). One of the OEMs indicated during the interviews that it needs to balance production three months ahead, and that the production schedule is then prepared on the basis of this forecast. ACMs base their production schedules on OEMs' production schedules. ACMs and their suppliers therefore work three months ahead of schedule. If the demand for motor cars suddenly declines, OEMs cancel orders immediately while the suppliers are in the process of working three months ahead. This leads to excessive pipeline inventory which is detrimental to all the parties higher up the supply chain.

The risks attached to a captive supplier, from the OEMs' perspective, are also problematic or risky from the ACMs' perspective. ACMs feel that they are too dependent on one or two customers. The situation can only change if South African ACMs can be more efficient and competitive, since that would encourage more local and even international OEMs to purchase components from them, thus leading to economies of scale. The current situation is also apparent in the imbalance of power between OEMs and ACMs. 


\section{CONCLUSION}

It is clear that a collaborative relationship and elements of a 'partnership' association exist between ACMs and their suppliers, and ACMs and their customers. ACMs indicated that they have good relationships with their suppliers and customers (OEMs), relationships that are based on trust and respect. Suppliers' financial difficulties and high purchasing prices bring uncertainty to the supply chains (i.e. from the supplier side). It is also apparent that an imbalance of power exists between ACMs and OEMs, and that ACMs are more at risk in uncertain circumstances than OEMs. The characteristic of 'openly deal with risks and incentives' in a partnership relationship is not clearly present between ACMs and OEMs. ACMs experience specific supply chain weaknesses with 1) pressure by OEMs on them (ACMs) to reduce selling prices; 2 ) cancellation of orders by OEMs because of the decline in demand for cars; 3) little or no assistance from OEMs; and 4) poor advanced communication from OEMs. These findings show that economic conditions have negatively influenced the automotive industry and that there is room for improvement in the level of cooperation between ACMs and OEMs in automotive supply chains.

OEMs are the dominant parties in the automotive supply chain and therefore the drivers of the supply chain. They operate closely with the final consumer in the supply chain and are the first to become aware of and experience any changes in the consumer market. They conduct research on technology, market trends and economic indicators, and should communicate this information continuously to their supply chain partners higher up the supply chain. More transparency and consideration of actions and reactions on market changes and real-time information is needed throughout the supply chain. The research indicates that partnerships between suppliers and customers in South African automotive supply chains are not applied to the fullest extent and to the full advantage of all partners in the chain.

The limitations of this research are that it only reflects $\mathrm{ACMs}^{\prime}$ views about relationships in the automotive supply chains. It is proposed that further research be conducted to explore the views of OEMs on the specific matters raised in this article. A more balanced view of the real relationships in South African automotive supply chains can be formed by comparing the views of the ACMs and OEMs. In conclusion, reflecting on the weaknesses experienced by ACMs it is clear that there is still evidence of a 'silo-approach' in automotive supply chains because in certain areas, certain members of the supply chain still focus solely on the advantage for their own organisation and not on any advantage to the supply chain as a whole. 


\section{REFERENCES}

AIEC (Automotive Industry Export Council). 2011. Automotive Export Manual. Pretoria: AIEC.

Barnes, J.R. 2002. World-class manufacturing as a necessary but insufficient condition for industry success: a case study of the South African automotive components industry. $\mathrm{PhD}$ thesis. University of KwaZulu-Natal, Durban.

Beth, S., Burt, D.N., Copacino, W., Gopal, C., Lee, H.L., Lynch, R.P. \& Morris, S. 2006. Supply chain challenges: building relationships. Harvard Business Review on Supply Chain Management. Boston: Harvard Business School Press.

Burt, D.N., Petcavage, S. \& Pinkerton, R. 2010. Supply management. 8th edition. Boston: Irwin McGraw-Hill.

Chan, F.T.S. \& Qi, H.J. 2003. An innovative performance measurement method for supply chain management. Supply Chain Management, 8(3):209-23.

Christopher, M. 2005. Logistics and supply chain management: Creating value-adding networks. Harlow, England: Prentice-Hall.

Fawcett, S.E., Ellram, L.M. \& Ogden, J. 2007. Supply chain management: from vision to implementation. Upper Saddle River, NJ. Pearson Prentice-Hall: xvii.

Ganesan, S, Brown, S.P., Mariadoss B.J. \& Ho, H. 2010. Buffering and amplifying effects of relationship commitment in business-to-business relationships. Journal of Marketing Research XLVII, April: 361-73.

Gullett, J., Do, L., Canuto-Carranco, M., Brister, M., Turner S. \& Caldwell, C. 2010. The buyer-supplier relationship: an integrative model of ethics and trust. Journal of Business Ethics (2009) 90: 329-41.

Liker, J.K. \& Choi, T.Y. 2006. Building deep supplier relationships. Harvard Business Review on Supply Chain Management. Boston: Harvard Business School Press.

Lysons, K. \& Gillingham, M. 2003. Purchasing and supply chain management. 6th edition. Harlow: Prentice-Hall Financial Times.

Monczka, R., Handfield, R., Giunipero, L.C., Patterson, J.L. \& Waters, D. 2010. Purchasing and supply chain management. 4th edition. Hampshire, UK: Cengage Learning.

Morgan, J. 2001. New survey finds big gap between rhetoric and reality. Purchasing, 15 November. Available from: http://www.manufacturing/net/pur (accessed 25 March 2008.) 
Morris, D., Donnelly, T. \& Donnelly, T. 2004. Supplier parks in the automotive industry. Supply Chain Management: An International Journal 9(2): 129-33.

NAACAM Newsletter, (9) March 2009. NAACAM BBEE Bulletin. Available from: www. naacam.co.za (accessed 8 August 2009.)

NAAMSA (National Association of Automobile Manufacturers of South Africa). 2010. Quarterly review of business conditions: Motor vehicle manufacturing industry. 1st Quarter, 2009.

Naude, M.J. \& Badenhorst-Weiss, J.A. 2011a. Supply chain management problems at South African automotive component manufacturers. Southern African Business Review 15(1): 70-99.

Naude M.J. \& Badenhorst-Weiss, J.A. 2011 b. The effect of problems on supply chain wide efficiency. Journal of Transport and Supply Chain Management: 278-98.

Pfeffer, J., Salancik, G.R. 1978. The external control of organizations. New York: Harper \& Row.

Pitot, R. 2007. NAACAM and the automotive component industry. South African Automotive Year Book. Definitive reference, statistics \& data on the South African motor industry. Section 2: component manufacturing. 10th edition. Durban: Balgair.

Quesada, G., Syamil, A. \& Doll, W.J. 2006. OEM new product development practices: the case of the automotive industry. The Journal of Supply Chain Management 42(3), Summer: 40-41.

Saunders, M. 1996. Strategic purchasing and supply chain management. 2nd edition. The Chartered Institute of Purchasing and Supply. London: Pitman (Financial Times).

Swink, M., Melnyk, S.A., Cooper, M.B. \& Hartley, J.L. 2011. Managing operations across the supply chain. New York: McGraw-Hill.

Tiziana, C. \& Mikolaj, J.P. 2005,. Power Imbalance, Mutual Dependence, and Constraint Absorption: A Closer Look at Resource Dependence Theory. Johnson Graduate School: Cornell University. Research Report: 167-99.

Trade Industry and Investment South Africa (TISA). 2003. Current developments in the automotive industry. 7th report. Pretoria: Department of Trade and Industry.

Van Weele, A.J. 2010. Purchasing \& supply chain management. 5th edition. Hampshire, UK: Cengage Learning. 
Venter, I. 2009a. SA auto industry could be dead in 7 years, warns WWSA. Engineering News. Available from: http://www.engineeringnews.co.za/article/sa-auto-industry-couldbe-dead-in-7-years (accessed 10 January 2010).

Venter, I. 2009b. Auto bosses wring their hands over SA's declining competitiveness. Can the situation be salvaged? Engineering News. Available from: http://www.engineeringnews. co.za/article/auto-bosses-wring-their-hands (accessed 20 July 2010).

Webster, S. 2008. Principles and tools for supply chain management. International edition. Boston: McGraw-Hill.

Williams, C. 2004. National association of automotive component and allied manufacturers. Available from: http://www.naacam.co.za/sami.htm (accessed 23 February 2004.)

Wisner, J.D., Tan, K.C. \& Leong, G.K. 2008. Principles of supply chain management: a balanced approach. Mason, $\mathrm{OH}$. South-Western Cengage Learning.

Wu, M.Y. \& Weng, Y.C. 2010. A study of supplier selection factors for high-tech industries in the supply chain. Total Quality Management 21(4), April: 391-413.

\section{ANNEXURE A}

\section{Profile of responding ACMS}

- The majority of respondents were managing directors (26.4\%) or director/general/ manager of operations (13.2\%). An almost equal spilt was obtained at the other levels of personnel involved in supply chain issues.

- The largest portion of respondents (24.5\%) had been in operation for between 11 and 20 years; 17\% between 21 and 30 years; and another $17 \%$ between 41 and 50 years. The remainder of ACMs had been operating for between 1 and 10 years or 51 and 60 years (11.3\% each). It could therefore be inferred that the responding ACMs were mature and well established (88.7\% had been in operation for more than 10 years).

- Most respondents were located in more than one geographical area (34\%), followed in number by those located in Gauteng (20.8\%), KwaZulu-Natal and the Eastern Cape (18.8\% each).

- The size of component manufacturers was measured in terms of number of employees. Respondents' companies employed 29346 workers in total.

- The majority of respondents' target customers were OEMs. Of the respondents, 20.8\% supplied to OEMs, while a further $20.8 \%$ supplied between $81 \%$ and $99 \%$ of their total sales to OEMs. Of the respondents, $34 \%$ and $24.5 \%$ supplied between $1 \%$ and $20 \%$ of their sales to original equipment suppliers and the aftermarket respectively. 
Table of acronyms

\begin{tabular}{|l|l|}
\hline ACM & Automotive Components Manufacturer \\
\hline AIEC & Automotive Industry Export Council \\
\hline GDP & Gross Domestic Product \\
\hline NAACAM & National Association of Automotive Component and Allied Manufacturers \\
\hline NAAMSA & National Association of Automobile Manufacturers of South Africa \\
\hline OEM & Original Equipment Manufacturer \\
\hline RDT & Resource Dependence Theory \\
\hline SCM & Supply Chain Management \\
\hline TISA & Trade Industry and Investment South Africa \\
\hline
\end{tabular}

